\title{
Polymorphisms of the programmed cell death 1 and ICOS genes and kidney transplant rejection in Iranian patients
}

\author{
Padideh Ebadi ${ }^{1 *}$, Mohammad Hossein Karimi ${ }^{2}$, Mohammad Taher Tahoori ${ }^{3}$, \\ Bita Geramizadeh ${ }^{2}$, Jamshid Roozbeh ${ }^{2}$, Kambiz Bagheri ${ }^{1}$, Behnam Mohammadi ${ }^{2}$ \\ and Ali reza Yousefi ${ }^{1}$ \\ ${ }^{1}$ Biochemistry Department, School of Medicine, Kazerun Branch, Islamic Azad University, Kazerun, Iran. \\ ${ }^{2}$ Transplant Research Center, Shiraz University of Medical Sciences, Shiraz, Iran. \\ ${ }^{3}$ Tarbiat Modares University, Immunology Department, Tehran, Iran.
}

Accepted 29 June, 2012

\begin{abstract}
Acute rejection is a common phenomenon in kidney transplantation. Inflammatory and anti inflammatory mediators affect graft microenvironment and its outcome. In this study, we evaluated the role of programmed cell death 1 (PD.1) and ICOS gene polymorphisms in the outcome of kidney transplantation. Polymerase chain reaction -Restriction fragment length polymorphism (PCR-RFLP) method using restriction enzymes was performed to characterize ICOS-693A/G,PD-1.1A/G polymorphisms in 100 kidney transplanted patients. Acute rejection episodes were diagnosed according to standard protocol. Analysis of the results showed that PD.1.1 AA genotype was significantly more frequent $(P=0.0001)$ in patients with acute rejection and $A$ allele was significantly more frequent $(P=0.006, O R=0.28,95 \% \mathrm{Cl}=0.09-0.82)$ in the patients without rejection. ICOS $-693 \mathrm{AA}$ genotype and $A$ allele were significantly more frequent $(P=0.03, O R=4.4,95 \% \mathrm{Cl}=0.85-22.46, P=$ $0.02, \mathrm{OR}=0.42,95 \% \mathrm{Cl}=0.19-0.96$ ) in rejecting patients, respectively. The present results show that studied gene polymorphisms have predictive values for acute rejection after renal transplantation. Further studies with consideration of different aspects in a larger group of patients would be more elucidative.
\end{abstract}

Key words: Inducible costimulator (ICOS), programmed cell death 1 (PD.1), gene polymorphism.

\section{INTRODUCTION}

For a kidney transplant acceptance with minimal inflammatory and immunological allografts damages, a proper balance in immune responses is needed. Both antigen-specific and non-antigen-specific co-stimulatory signals are necessary for naive $T$ lymphocytes. The extent of activation and its phenotypic outcome are modulated by these complementing signals (Kusztal et al., 2010; Lee et al., 1998). CD28 gene family (e.g. PD.1, ICOS) consists of major co-stimulators which interact with

\footnotetext{
${ }^{\star}$ Corresponding author. E-mail: Padideh_ebadi@yahoo.com.
} Fax: 00987212230508. the molecules of their ligands on antigen-presenting cells. ICOS-ICOSL interactions make a positive signal for T-cell activation and amplify the immune response. $T$ lymphocytes activation and the production of several cytokines are due to this signal (Rothstein et al., 2003). In contrast, a down-regulatory molecule named programmed cell death 1 (PD.1), dampens the response through a variety of means and stops the immune response. It also blocks T-cell activity and terminates $T$ cell response by inhibiting the signals stimulated by PDL. The precise mechanism of PD.1 mediated T cell inhibition is not clearly defined, but PD. 1 induced signals are the candidates for this phenomenon (Rothstein et al., 2003; 
Keir et al., 2007). T-cell co-stimulatory activation pathway has been implicated in transplant rejection episodes (Kim et al., 2010). Several genes participate in this process and polymorphisms in these genes may affect transplant outcome (Slavcheva et al., 2001; Haimila et al., 2009; Krichen et al., 2009).

ICOS and PD.1 pathways are critical for the development of Th1 vs. Th2 responses. Both have the potential to initiate a proliferation response and the balance of Th1/Th2 subsets influenced by the intensity of T-cell co-stimulatory signals (Smith et al., 2003). Several important polymorphic sites, like the two in the exon 5 region $(7785 \mathrm{C} / \mathrm{T}, 7625 \mathrm{~T} / \mathrm{C})$, and the one in intron region (7146G/A) have been found in PD.1 gene (Liu et al., 2011). The association of PD.1 and ICOS polymorphisms with autoimmune diseases has been previously shown (Wang et al., 2008; Velázquez-Cruz et al., 2007; Kroner et al., 2005). Many studies conducted in vitro and in vivo showed the importance of co-stimulatory pathway in the regulation of immune tolerance (Elster et al., 2004). In particular, some studies of genetic polymorphisms in human liver and kidney transplantation have suggested that co-stimulatory molecules may play a minor role in the allograft rejection (Slavcheva et al., 2001; Haimila, 2009; Krichen et al., 2009). Many of the reports have been inconclusive; although there has been no study of genetic associations of PD.1 and ICOS gene in Iranian renal allograft recipients. In this study, we investigated 100 Iranian renal allograft recipients to determine the distribution of genotypes and allele frequencies of an important polymorphism in PD.1 gene (PD.1.1 rs36084323 A/G) and also, a polymorphism in ICOS gene (rs11883722 $-693 \quad A / G)$ associated with susceptibility to acute rejection (AR).

\section{MATERIALS AND METHODS}

In the current study, one hundred consecutive patients who received kidney transplants between May 2006 and February 2008 were enrolled. All the patients were Iranian and had transplant operations at the Transplantation Center of Nemazi Hospital, affiliated to Shiraz University of Medical Sciences, Shiraz, Iran. The study was approved by the Ethics Committee of the university.

We investigated the graft outcome and acute rejection episode(s) in the aforementioned patients for at least 4 months. Donors were selected on the basis of $\mathrm{ABO}$ blood group compatibility and all the patients were negative for lymphocytotoxic cross matches. The patients were divided into two groups according to the presence (AR group) or absence (non-AR group) of acute rejection episodes. Non-rejected transplant patients were considered as the control group. Rejection episodes were identified by an expert nephrology team based on the approved clinical diagnostic criteria and invariably confirmed by needle biopsy as well as elevated serum creatinine and blood urea nitrogen levels (Solez et al., 2008). The standard immunosuppressive regimen for all 100 recipients included cyclosporine $(5 \mathrm{mg} / \mathrm{kg}$ initially, then a maintenance dose of 2 to $2.5 \mathrm{mg} / \mathrm{kg}$; cyclosporine level was 50 to $150 \mathrm{ng} / \mathrm{ml}$ ), prednisolone $(120 \mathrm{mg} /$ day initially, tapering to $10 \mathrm{mg} /$ day $)$, and mycophenolate mofetil (1000 mg twice daily). Acute rejection was initially treated with intravenous steroids and steroid-resistant rejection was treated with OKT3 monoclonal antibody.

\section{DNA extraction}

The buffy coat of the whole blood from renal transplanted patients was available in the sample bank affiliated to Shiraz Transplant Research Center. Genomic DNA was extracted from the buffy coat using a QIAamp DNA Mini Kit (Qiagen, Germany), according to the manufacturer's instructions.

\section{Genotyping}

Co-stimulatory molecules gene polymorphisms were evaluated by polymerase chain reaction using a thermal cycler (Eppendorf, UK). PCR conditions, PCR cycles and primers were summarized in Tables 1 and 2. PCR-RFLP method was carried out for PD.1.1 A/G (Ferreiros-Vidal et al., 2004), and ICOS-693 A/G (Haimila et al., 2004), genotyped in $10 \mu \mathrm{l}$ reaction mixtures. After PCR, the products were digested by restriction enzyme and the amplified products were monitored by agarose gel electrophoresis and ethidium bromide staining.

\section{Statistical analysis}

Allele and genotype frequencies were calculated in the patients and controls by direct gene counting. Statistical analysis was performed using SPSS version 15. The frequencies of the alleles/genotypes were compared in the patients and controls by Chi-square test and Fisher's exact test. Odds ratios and 95\% confidence intervals (Cls) for relative risks were calculated. A probability value of $\mathrm{P}<0.05$ was considered as statistically significant and all the reported $p$-values were two-tailed. LD2SNPing program V 2.0 (http://www.bio .kuas.edu.tw/LD2SNPing) was used to estimate linkage disequilibrium.

\section{RESULTS}

Among 100 consecutive recipients, $60 \%$ were males and $40 \%$ were females with a mean \pm SD age of $39.5 \pm 8.6$ years. The mean age of the patients with an acute rejection episode was $39.1 \pm 10.2$ years and in those with normal organ function, it was $41.1 \pm 9.3$ years. The differences in age between two groups were not significant $(P=0.415)$. Male to female ratio $(M / F)$ was in the rejecting group $67 \% / 33 \%$ and $59 \% / 41 \%$ in the nonrejecting group. Overall, 18 (18\%) recipients experienced an acute rejection. In this study, the mean of donor age is $34.5 \pm 9.0$ years. Most of the donors were cadaveric and unrelated. The ratio of living/cadaveric to related/unrelated were 0.9 and 0.54 , respectively. After sex classification, the results showed no significant differences between rejected and non-rejected groups. The frequencies of PD.1.1A/G and ICOS-693 A/G gene in the transplanted patients are shown in Table 3. PD.1.1, AA genotype was significantly more frequent $(P=0.0001$, study power $=48 \%$ ) in patients with acute rejection and $A$ allele was significantly more frequent $(P=0.006, O R=$ $0.28,95 \% \mathrm{Cl}=0.09-0.82$, study power $=54 \%$ ) in patients without rejection. ICOS-693 AA genotype and A 
Table 1. The PCR thermo cycling condition for the ICOS and PD.1.1.

\begin{tabular}{ll}
\hline Locus & PCR condition \\
\hline PD. 1.1 & $95^{\circ} \mathrm{C} 4 \min 1 \mathrm{Cycle}, 30$ Cycle: $95^{\circ} \mathrm{C} 60 \mathrm{~s} 59^{\circ} \mathrm{C}: 60 \mathrm{~s}, 72^{\circ} \mathrm{C} 60 \mathrm{~s}, 72^{\circ} \mathrm{C}: 5 \min 1$ Cycle \\
ICOS-693 & $95^{\circ} \mathrm{C} 5 \min 1 \mathrm{Cycle}, 30$ Cycle: $95^{\circ} \mathrm{C} 50 \mathrm{~s} 61^{\circ} \mathrm{C}: 60 \mathrm{~s}, 72^{\circ} \mathrm{C} 60 \mathrm{~s}, 72^{\circ} \mathrm{C}: 7$ min 1 Cycle \\
\hline
\end{tabular}

Table 2. The Primers and types of PCR for the ICOS and PD.1.1.

\begin{tabular}{lll}
\hline Locus & Primer & Method \\
\hline PD.1.1 & Forward primer: 5'-CTCAACCCCACTCCCATTCT-3' & Mspl based RFLP \\
& Reverse primer:5'-TTCTAGCCTCGCTTCGGTTA-3' & \\
ICOS-693 & Forward primer:5'-ATTTCTATCTTATGCTAGGTGCTCCA-3' & BseGl based RFLP \\
\hline
\end{tabular}

Table 3. Results of ICOS -693A/G, PD.1.1 A/G single nucleotide polymorphism determined in 100 kidney transplant patients.

\begin{tabular}{llccccc}
\hline Gene & Genotype & Reject N (\%) & Non-reject N (\%) & P value & OR & 95\% Cl \\
\hline \multirow{5}{*}{ ICOS-693 } & GG & $7(38.9)$ & $49(59.8)$ & 0.15 & 0.43 & $0.13-1.36$ \\
& GA & $7(38.9)$ & $28(34.1)$ & 0.7 & 1.23 & $0.38-3.93$ \\
& AA & $4(22.2)$ & $5(6.1)$ & $0.03^{*}$ & 4.4 & $0.85-22.46$ \\
& A allele & $21(58.3)$ & $126(24.2)$ & $0.02^{*}$ & 0.42 & $0.19-0.96$ \\
& G allele & $15(41.7)$ & $38(75.8)$ & & & \\
\multirow{5}{*}{ PD.1.1 } & & & & & \\
& GG & $13(72.2)$ & $70(85.3)$ & 0.18 & 0.45 & $0.12-1.75$ \\
& GA & $2(11.1)$ & $12(14.7)$ & 0.69 & 0.73 & $0.1-4.01$ \\
& AA & $3(16.7)$ & $0(0)$ & $0.0001^{* *}$ & ---------- & ---------- \\
& G allele & $28(77.8)$ & $152(92.7)$ & $0.006^{* *}$ & 0.28 & $0.09-0.82$ \\
\hline
\end{tabular}

$\mathrm{N}$, absolute number; $\mathrm{Cl}$, confidence interval; OR, odds ratio; ${ }^{*}$ Considered significant after the Bonferroni correction $(\mathrm{P}$ value threshold of 0.017 ). ${ }^{*}$ Considered significant with $P$ value threshold of 0.05 In genotypes, each $P$ value is the result of comparing corresponding row with the sum of other rows.

allele were significantly more frequent $(P=0.03, \mathrm{OR}=$ $4.4,95 \% \mathrm{Cl}=0.85-22.46$, study power $=35 \%, \mathrm{P}=0.02$, $\mathrm{OR}=0.42,95 \% \mathrm{Cl}=0.19-0.96$, study power $=97 \%$ ) in rejecting patients, respectively. The significance of these alleles and genotypes, however, did not survive the Bonferroni correction, which suggested the striking of $\mathrm{P}$ value threshold from conventional 0.05 to 0.017 .

The ICOS-693A/G,PD.1.1A/G is fitted to HardyWeinberg equilibrium. The PD.1.1 and ICOS-693 haplotypes were deduced in the rejecting and nonrejecting patients. Results are presented in Table 4 . The most frequent haplotypes in the rejecting and nonrejecting patients were GG. Compared with rejecting group, in non rejecting ones, the frequencies of $G G$ haplotype was higher $(P=0.02)$. A linkage disequilibrium $\left(D^{\prime}=0.28, P<0.030\right.$ ) was found for two polymorphisms at the positions ICOS-693A/G and PD.1.1A/G (Figure 1).

\section{DISCUSSION}

Apart from several non immunologic factors such as thrombosis, graft failure has different significant immunological reasons. For example, an undesirable immune response can be mediated by $T$ cells and thus studying the molecules participating in the regulation of T-cell activity is absorbing. The precise regulation of lymphocyte activation is dependent on the positive and negative signals received from co-stimulatory and coinhibitory receptors including ICOS and PD. 1 expressed on T lymphocyte (Rothstein et al., 2003; Frauwirth et al., 2002). T cell mediated immune responses have a crucial role in the kidney allograft rejection. Thus, suitable balance between these signals determines the outcome of an immune response to kidney allograft. Polymorphisms in co-stimulatory molecule genes are 
Table 4. Frequencies of ICOS (ICOS-693A/G) and PD.1.1A/G haplotypes in rejecting and non-rejecting kidney transplant patients.

\begin{tabular}{lccc}
\hline Possible haplotype & Rejecting N (\%) & Non-rejecting N (\%) & P value \\
\hline GG & $19(52.8)$ & $118(71.2)$ & 0.02 \\
GA & $4(11.2)$ & $6(3.6)$ & 0.06 \\
AA & $4(11.2)$ & $7(4.2)$ & 0.1 \\
AG & $9(25)$ & $33(20.1)$ & 0.5 \\
\hline
\end{tabular}

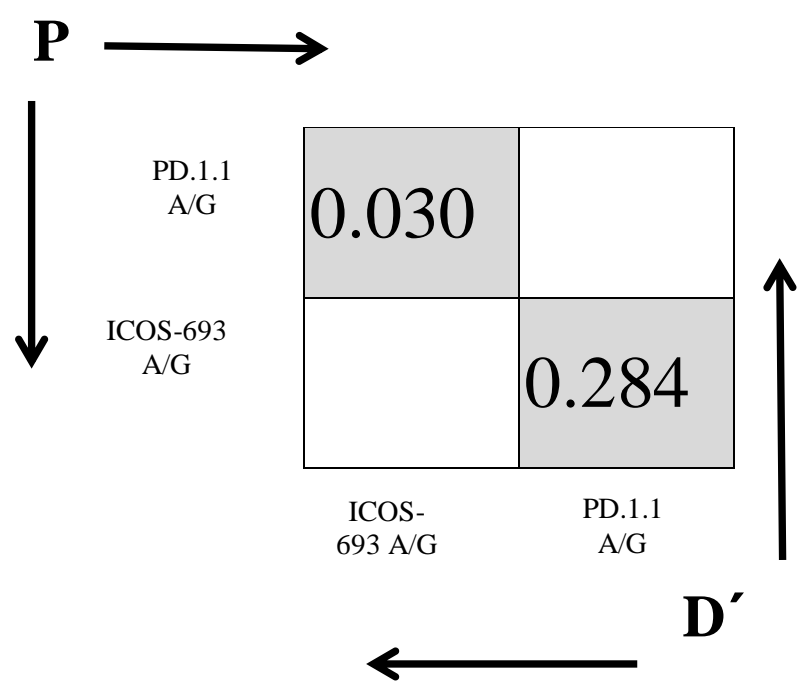

Figure 1. Linkage disequilibrium plot of PD.1 and ICOS polymorphisms in ' $D^{\prime}$ value. Dark color boxes are representative of high linkage disequilibrium (LD) and light color boxes indicate low LD. The left upper boxes indicate the $P$ values.

genetic susceptible factors for graft rejection (Haimila et al., 2009). Herein, we revealed that ICOS-693 and PD1.1 markers correlate with acute rejection. The ICOS602A/C, ICOS1564C/T and PD-1.3 variations are noncoding SNPs, so they do not change the amino acid sequences. ICOS functions as a regulator of $\mathrm{T}$-cell activation and differentiation, also its signaling plays an important role in CD40-mediated antibody class switching. Ozkaynak et al. (2001) demonstrated the importance of ICOS in the promotion of both acute and chronic rejections. In addition, blocking the ICOS pathway prolonged the graft survival (Ozkaynak et al., 2001; Harada et al., 2003). Present studies show the genetic association between ICOS and the outcome of transplant. Also blocking studies clearly indicate that ICOS is a principal factor in determining the graft function. So, we hypothesized that these polymorphisms might influence the allogenic kidney graft rejection in Iranian population

As our results indicated, AA genotype and A allele of ICOS are of higher frequencies in rejecting patients. Considering the fact that different SNP alleles relating to
ICOS and PD.1 genes are located in the promoter and can probably influence their expression, in an alternative study, CD28/CTLA4/ICOS gene polymorphism effects on the kidney transplant outcome was studied and it was shown that ICOS gene was associated with rejection (Haimila et al., 2009). The findings of Ozkaynak suggest that the regulation of this pathway may be of key importance in promoting successful transplantation and possibly in treating autoimmune diseases. Ozkaynak et al. (2001) also found that both anti-ICOS and an ICOS-Ig fusion protein controlled intragraft $\mathrm{T}$ cell activation and cytokine expression and prolonged allograft survival such as ICOS-/-allograft recipients. ICOS knockout mice have reduced CD4+ T cell responses (Dong et al., 2001). AntiICOS antibody treatment has also been studied together with anti-CD40L and CTLA4-Ig in animal models of transplantation. The animals displayed fewer signs of chronic rejection (Snanoudj et al., 2006). We also investigated another polymorphism. We found that in PD1.1 the frequency of AA genotype and A allele in rejecting group was lower than those of in non-rejecting group, which indicate that AA genotype might be a risk 
factor for rejection development. As it is known, mutations in the promoter region may influence the engagement between sequence motifs and transcription factors, which inhibit the activation of gene and the initiation of transcription (de Vooght et al., 2009). Therefore, since a polymorphism located in the promoter of PD-1 gene, PD-1.1 may also affect the transcription and activation of PD-1 gene, and influence the development of rejection (Hua et al., 2011). Furthermore previous reports have shown that PD-1.1 AA genotype and $A$ allele are associated with a decreased risk of RA (Kong et al., 2005). We also found that PD-1.1 was probably associated with the susceptibility to rejection. Hence, PD-1.1 may be a functional polymorphism which can influence the risk of diseases. Recently, Hancock et al. have studied the functions of PD.1 and its ligands in the cardiac allograft rejection of mice (Ozkaynak et al., 2002). Holopainen and Partanen reported strong LD on the 2q33 region (Holopainen and Partanen, 2001, Holopainen et al., 2004). These four genes are situated adjacent to each other on the chromosome region 2q3337 (Haimila et al., 2004). Thus, we evaluated the relationship between LD and haplotype of ICOS and PD.1 in the promoter with kidney allograft rejection. The frequencies of $G G$ and $G A$ haplotype in rejecting and non-rejecting were lower than those in controls $(P=0.02$ and $P=0.06$, respectively). Therefore, $G G$ haplotype may also be important risk factor for the development of rejection. It is clarified that PD-1.1 and CTLA4-1722 markers are in strong linkage disequilibrium. All of this experimental evidence confirm the role of ICOS and PD.1 gene SNP in the kidney transplant rejection and agree with our results.

We examined 2SNPs and the results suggested that ICOS and PD.1 are the genetic factors affecting the kidney transplant outcome. This study was carried out with a relatively small group of patients. Continued efforts to confirm and extend the present results are crucial. In conclusion, a set of specific alleles in ICOS and PD.1 genes regulate $\mathrm{T}$-cell activation of the co-stimulatory pathway and influence the kidney transplant outcome.

\section{ACKNOWLEDGEMENT}

The authors thank Transplant Research Center, Shiraz University of Medical Sciences.

\section{REFERENCES}

de Vooght KM, van Solinge WW (2009). Gene promoter analysis in molecular diagnostics: do or don't? Expert Rev. Mol. Diagn. 9(5):403405.

Dong C, Juedes AE, Temann UA, Shresta S, Allison JP, Ruddle NH, Flavell RA (2001). ICOS co-stimulatory receptor is essential for T-cell activation and function. Nature 409(6816):97-101.

Elster EA, Hale DA, Mannon RB, Cendales LC, Swanson SJ, Kirk AD (2004). The road to tolerance: renal transplant tolerance induction in nonhuman primate studies and clinical trials. Transpl. Immunol.
13:87.

Ferreiros-Vidal I, Gomez-Reino JJ, Barros F, Carracedo A, Carreira P, Gonzalez-Escribano F, Liz M, Martin J, Ordi J, Vicario JL, Gonzalez A (2004). Association of PDCD1 with susceptibility to systemic lupus erythematosus evidence of population-specific effects. Arthritis Rheum. 50(8):2590-2597.

Frauwirth KA, Thompson CB (2002). Activation and inhibition of lymphocytes by costimulation. J. Clin. Invest. 109(3):295-299.

Haimila K, Smedberg T, Mustalahti K, Mäki M, Partanen J, Holopainen $P$ (2004). Genetic association of coeliac disease susceptibility to polymorphisms in the ICOS gene on chromosome 2q33. Genes Immun. 5(2):85-92.

Haimila K, Turpeinen H, Alakulppi NS, Kyllönen LE, Salmela KT, Partanen J (2009). Association of genetic variation in inducible costimulator gene with outcome of kidney transplantation. Transplantation 87(3):393-396.

Holopainen P, Naluai AT, Moodie S Percopo S, Coto I, Clot F, Ascher H, Sollid L, Ciclitira P, Greco L, Clerget-Darpoux F, Partanen J (2004). Candidate gene region 2 q33 in European families with coeliac disease. Tissue Antigens 63:212-222.

Holopainen PM, Partanen JA (2001). Technical Note: Linkage disequilibrium and disease-associated CTLA4 gene polymorphisms. J. Immunol. 167(5):2457-2458.

Hua Z, Li D, Xiang G, Xu F, Jie G, Fu Z, Jie Z, Da P, Li D (2011). PD-1 polymorphisms are associated with sporadic breast cancer in Chinese Han population of Northeast China. Breast Cancer Res. Treat. 129(1):195-201

Keir ME, Francisco LM, Sharpe AH (2007). PD-1 and its ligands in Tcell immunity. Curr. Opin. Immunol. 19:309-314.

Kim HJ, Jeong KH, Lee SH, Moon JY, Lee TW, Kang SW, Park SJ, Kim $\mathrm{YH}$, Chung JH (2010). Polymorphisms of the CTLA4 gene and kidney transplant rejection in Korean patients. Transplant Immunol, 24:4044.

Kong EK, Prokunina-olsson L, Wong WH, Lau CS, Chan TM, AlarcónRiquelme M, Lau YL (2005). A new haplotype of PDCD1 is associated with rheumatoid arthritis in Hong Kong Chinese. Arthritis Rheum. 52:1058-1062.

Krichen H, Sfar I, Jendoubi-Ayed S, Makhlouf M, Ben RT, Bardi R, Aouadi H, Ben AT, Ayed K, Gorgi Y (2009). Genetic polymorphisms of immunoregulatory proteins in acute renal allograft rejection. Transplant Proc. 41(8):3305-3307.

Kroner A, Mehling M, Hemmer B, Rieckmann P, Toyka KV, Mäurer M, Wiendl H (2005). A PD-1 polymorphism is associated with disease progression in multiple sclerosis. Ann. Neurol. 58:50-57.

Kusztal M, Kościelska-Kasprzak K, Drulis-Fajdasz D, MagottProcelewska M, Patrzałek D, Janczak D, Chudoba P, Klinger M (2010). The influence of CTLA-4 gene polymorphism on long-term kidney allograft functions in Caucasian recipients. Transplant Immunol. 23:121-124.

Lee KM, Chuang E, Griffin M, Khattri R, Hong DK, Zhang W, Straus D, Samelson LE, Thompson CB, Bluestone JA (1998). Molecular basis of $T$ cell inactivation by CTLA-4. Science 282:2263-2266.

Liu X, Hu LH, Li YR, Chen FH, Ning Y, Yao QF (2011). Programmed cell death 1 gene polymorphism is associated with ankylosing spondylitis in Chinese Han population. Rheumatol. Int. 31:209-213.

Ozkaynak E, Gao W, Shemmeri N, Wang C, Gutierrez-Ramos JC, Amaral J, Qin S, Rottman JB, Coyle AJ, Hancock WW (2001). Importance of ICOS-B7RP-1costimulation in acute and chronic allograft rejection. Nat. Immunol. 2:591-596.

Ozkaynak E, Wang L, Goodearl A ,McDonald K, Qin S, O'Keefe T, Duong T, Smith T, Gutierrez-Ramos JC, Rottman JB, Coyle AJ, Hancock WW (2002). Programmed death-1targeting can promote allograft survival. J. Immunol. 169:6546-6553.

Rothstein DM, Sayegh MH (2003). T-cell costimulatory pathways in allograft rejection and tolerance. Immunol. Rev. 196:85-108.

Slavcheva E, Albanis E, Jiao Q, Tran H, Bodian C, Knight R, Milford E, Schiano T, Tomer Y, Murphy B (2001). Cytotoxic Tlymphocyte antigen 4 gene polymorphisms and susceptibility to acute allograft rejection. Transplantation 72(5):935-940.

Smith KM, Brewer JM, Webb P, Coyle AJ, Gutierrez-Ramos C, Garside $P$ (2003). Inducible costimulatory molecule-B7-related protein 1 interactions are important for the clonal expansion and B cell helper 
functions of naive, Th1, and Th2 T cells. J. Immunol. 170(5):23102315.

Snanoudj R, de Préneuf H, Créput C Arzouk N, Deroure B, Beaudreuil S, Durrbach A, Charpentier B (2006). Costimulation blockade and its possible future use in clinical transplantation. Transpl. Int. 19(9):693704.

Solez K, Colvin RB, Racusen LC, Haas M, Sis B, Mengel M, Halloran PF, Baldwin W, Banfi G, Collins AB, Cosio F, David DS, Drachenberg C, Einecke G, Fogo AB, Gibson IW, Glotz D, Iskandar SS, Kraus E, Lerut E, Mannon RB, Mihatsch M, Nankivell BJ, Nickeleit V, Papadimitriou JC, Randhawa P, Regele H, Renaudin K, Roberts I, Seron D, Smith RN, Valente M (2008). Banff 07 classification of renal allograft pathology: updates and future directions. Am. J. Transplant. 8:753-760.
Velázquez-Cruz R, Orozco L, Espinosa-Rosales F, Carreño-Manjarrez R, Solís-Vallejo E, López-Lara ND, Ruiz-López IK, Rodríguez-Lozano AL, Estrada-Gil JK, Jiménez-Sánchez G, Baca V (2007). Association of PDCD1 polymorphisms with childhood-onset systemic lupus erythematosus. Eur. J. Hum. Genet. 15:336-341.

Wang Q, Ye D, Yin J, Li X, Zhang G, Zhang Y, Zhang X (2008). Programmed cell death 1 genotypes are associated with susceptibility to systemic lupus erythematosus among Chinese. Arch. Dermatol. Res. 300:91-93. 